\title{
Did Enterprises' Innovation Ability Increase During the COVID-19 Pandemic? Evidence From Chinese Listed Companies
}

\author{
Hongfang Han ${ }^{1}$ Yanhong Qian ${ }^{1}$ a \\ 1 Zhejiang University of Finance \& Economics, China \\ Keywords: listed company, innovation ability, covid-19 \\ 10.46557/001c.18072
}

\section{Asian Economics Letters}

\begin{abstract}
This paper uses a fixed effect model to empirically study the impact of COVID-19 on the innovative ability of listed companies in China. We find that the innovative abilities of Chinese listed companies, both large-scale and small-scale, increase during the pandemic. Moreover, the impact of COVID-19 varies by industry. These results may enhance market confidence and have implications for policy formulation and economic recovery.
\end{abstract}

\section{Introduction}

The outbreak of the novel coronavirus pandemic (COVID-19) in 2020 seriously impacted China's economy. ${ }^{1}$ Wen et al. (2020) study the impact of COVID-19 on China's economy and find that the shutdown directly affects the output of enterprises, resulting in a reduction of capital utilization and investment, and the decline in consumption demand. Thus, the pandemic may inhibit the innovative ability of enterprises. On the other hand, sustainable innovation is imperative for the survival and success of organizations in the turbulent market environment of the digital age, especially during the current COVID-19 pandemic crisis (Lee \& Trimi, 2020). Innovation helps to improve the value chain for the organization and its stakeholders (Harrison \& Freeman, 1999). Our hypothesis, therefore, is that the COVID-19 pandemic may enhance the innovation ability of enterprises.

In this paper, we empirically study the impact of the pandemic on the innovative ability of Chinese enterprises to provide some reference for the government to formulate relevant policies and reduce the impact of the pandemic on China's economy. We use 3,001 A-share listed companies in China from the first quarter of 2019 to the second quarter of 2020 as our study sample. Using a fixed effect model and the panel data, empirical results show that the pandemic has a significantly positive impact on the innovative ability of companies with different scales. This impact is more significant in industries such as information technology, medical $\&$ health, materials, industry, real estate, necessary consumer and unnecessary consumer goods.

Although the COVID-19 pandemic is believed to accelerate enterprise innovation, none of the studies to-date have tested the effects of COVID-19 on innovation. We choose China for our study because China was the first country to announce the outbreak of COVID-19 and is the most successful in mitigating the effects of the pandemic. Through rigorous empirical analysis, this paper provides an insight on how Chinese listed companies innovate during the crisis.

The remainder of this paper proceeds as follows. Section II provides data and research methodologies; Section III presents the empirical results; and Section IV concludes this paper.

\section{Data and Methodology}

We select all the A-share listed companies in China as the sample. After excluding the observations with missing information, the data sample includes 3,001 listed companies ${ }^{2}$. The data period used in this paper is from the first quarter of 2019 to the second quarter of 2020. Due to the lag in the disclosure of financial data of listed companies, the panel data ends in the second quarter of 2020. Since the impacts of the pandemic generally last no more than one quarter (Keogh-Brown \& Smith, 2008), we believe that we can already capture the short-term impacts of COVID-19 with such a short panel.

Scholars have adopted a variety of methods to capture the innovation performance of enterprises, such as R\&D investment, the number and citation of patents, and the number of new-developed products, etc. (Zhao et al., 2020). In Wen et al. (2020), they use R\&D investment as the main dependent variable to investigate the impact of bank lending intervention on firm innovation. Following them, in this paper, we use the logarithm of $R \& D$ investment per quarter $(\ln R D)$ as a proxy for innovation ability of enterprises. The independent variable (COVID19) is the severity of COVID-19, measured by the number of days of the firstlevel public health emergency response initiated by each province in China. We divide the listed companies by province to match independent variables and other control variables.

To eliminate estimation bias, we include two control variables. One is regional quarterly GDP in logarithm form

\footnotetext{
a Corresponding author: Corresponding author: China Academy of Financial Research, Zhejiang University of Finance \& Economics. No.18, Xueyuan Street, Xiasha Higher Education Zone, Hangzhou Zhejiang 310018, P.R. China. Email: yhqian@zufe.edu.cn

Helpful comments and suggestions from a referee of this journal is acknowledged.

1 See Iyke (2020).

2 The data can be obtained from iFinD (http://www.51ifind.com/).
} 
Table 1: Descriptive statistics

\begin{tabular}{lccccccc}
\hline & Variable & Unit & N & Mean & SD & Min & Max \\
\hline Dependent variable & $\ln R D$ & RMB & 16,566 & 16.60 & 1.571 & 4.120 & 23.78 \\
Independent variable & COVID19 & Day & 16,566 & 8.367 & 17.40 & 0 & 67 \\
Control variables & $\ln$ SDP & 100million RMB & 16,566 & 9.414 & 0.689 & 5.923 & 10.32 \\
& $\ln F I N$ & 100millionRMB & 16,566 & 8.231 & 1.059 & 2.036 & 9.606 \\
\hline
\end{tabular}

This table contains descriptive statistics of dependent variable ( $\ln R D$ ), the independent variable (COVIDI9), and the two control variables, $\ln G D P$ and $\ln F I N$. The unit of measurement is in column 3. $\mathrm{N}$ is the total number of observations. The variables mean, standard deviation (SD), minimum (Min) and maximum (Max) are given.

Table 2: The results of the main regression

\begin{tabular}{|c|c|c|c|}
\hline & whole sample & small-scale companies & large-scale companies \\
\hline \multirow[t]{2}{*}{ COVIDI9 } & $0.005^{* * *}$ & $0.005^{* * *}$ & $0.005^{* * *}$ \\
\hline & $(0.000)$ & $(0.000)$ & $(0.001)$ \\
\hline \multirow[t]{2}{*}{$\ln G D P$} & $2.977^{* * *}$ & $2.930^{* * *}$ & $3.085^{* * *}$ \\
\hline & $(0.078)$ & $(0.094)$ & $(0.136)$ \\
\hline \multirow[t]{2}{*}{$\ln F I N$} & $-0.075^{* * *}$ & $-0.080^{* * *}$ & $-0.065^{* * *}$ \\
\hline & $(0.009)$ & $(0.011)$ & (0.018) \\
\hline Time fixed effect & Yes & Yes & Yes \\
\hline $\mathrm{R}$-squared & 0.216 & 0.208 & 0.238 \\
\hline Observations & 16,566 & 11,504 & 5,062 \\
\hline
\end{tabular}

This table has the main regression results. The results are for three panels of firms: whole sample, small-scale companies and large-scale companies. Clustered standard errors at the firm level are in parentheses, and ${ }^{* * * *} \mathrm{p}<0.01,{ }^{* * *} \mathrm{p}<0.05,{ }^{*} \mathrm{p}<0.1$.

( $\operatorname{lnGDP}$ ) following Zhang et al. (2019), and the other is regional social financing scale also in logarithm form $(\operatorname{lnFIN})$, following Jia (2020). Table 1 reports the descriptive statistics of all the variables.

Considering the individual effects in different companies, we employ a fixed effect model to conduct the regressions. The Hausman test also supports the use of a fixed effects model instead of a random effect one. The model is stated as follows:

$$
\ln R D_{i t}=\beta C O V I D 19_{i t}+\theta \text { Control }_{i t}+\mu_{i}+\varepsilon_{i t}
$$

We also include year dummy variables to control the time effects. In addition, we perform robustness checks by using subsamples with different scales. We define the companies whose market values are more than 8 billion as large-scale companies, and small-scale companies otherwise (Xiao, 2013).

Further, we conduct subsample tests to analyze the heterogeneity of the effects of COVID-19 in different industries. According to GICS (Global Industry Classification Standard), all the companies in the sample belong to 11 industries, including information technology, utilities, medical \& health, materials, industry, real estate, necessary consume, energy, telecom, finance, and unnecessary consume.

\section{Empirical Findings}

Table 2 shows the main effects of COVID-19. In Column 1 , the coefficient of COVID-19 is positive and significant at the $1 \%$ level, indicating that the pandemic positively impacts the R\&D investment of listed companies. The coefficient of COVID-19 is 0.005 , which means that a one-standard-deviation increase in the emergency response days is associated with an increase of $8.613 \%$ in innovation input. The subsample tests in Columns 2 and 3 verify the positive effects of COVID-19. For both large-scale and small-scale companies, their innovation abilities significantly increase during the pandemic. Faced with the pandemic, enterprises tend to increase innovation input to seek new opportunities to survive and make profits.

As shown in Table 3, the positive impact of COVID-19 in different industries varies in significance level. The impact is significant at the $1 \%$ level for information technology, medical \& health, materials, industry, real estate, necessary consume and unnecessary consume; at the $5 \%$ level for utilities and finance; and at the 10\% level for energy and telecom. 
Table 3: Regression results of enterprises in different industries

\begin{tabular}{|c|c|c|c|c|c|c|c|c|c|c|c|}
\hline & $\begin{array}{l}\text { Information } \\
\text { technology }\end{array}$ & Utilities & $\begin{array}{c}\text { Medical \& } \\
\text { Health }\end{array}$ & Materials & Industry & $\begin{array}{l}\text { Real } \\
\text { estate }\end{array}$ & $\begin{array}{l}\text { Necessary } \\
\text { consume }\end{array}$ & Energy & Telecom & Finance & $\begin{array}{l}\text { Unnecessary } \\
\text { consume }\end{array}$ \\
\hline \multirow[t]{2}{*}{ COVID19 } & $0.003^{* * *}$ & $0.005^{* *}$ & $0.006^{* * *}$ & $0.007^{* * *}$ & $0.005^{* * *}$ & $0.006^{* * *}$ & $0.005^{* * *}$ & $0.006^{*}$ & $0.006^{*}$ & $0.008^{* *}$ & $0.004^{* * *}$ \\
\hline & $(0.001)$ & $(0.002)$ & $(0.001)$ & $(0.001)$ & $(0.001)$ & $(0.002)$ & $(0.001)$ & $(0.003)$ & $(0.004)$ & $(0.003)$ & $(0.001)$ \\
\hline \multirow[t]{2}{*}{$\ln G D P$} & $2.780^{* * *}$ & $2.685^{* * *}$ & $3.115^{* * *}$ & $3.297^{* * *}$ & $2.985^{* * *}$ & $3.235^{* * *}$ & $2.762^{* * *}$ & $2.356^{* * *}$ & $3.014^{* * *}$ & $2.828^{* * *}$ & $3.063^{* * *}$ \\
\hline & $(0.152)$ & $(0.506)$ & $(0.247)$ & (0.194) & $(0.172)$ & $(0.464)$ & $(0.291)$ & $(0.514)$ & $(0.584)$ & $(0.650)$ & $(0.204)$ \\
\hline \multirow[t]{2}{*}{$\ln F I N$} & $-0.053^{* * *}$ & -0.032 & $-0.067^{* * *}$ & $-0.107^{* * *}$ & $-0.070^{* * *}$ & $-0.085^{* *}$ & $-0.064^{*}$ & -0.080 & -0.038 & -0.327 & $-0.062^{* * *}$ \\
\hline & (0.019) & (0.051) & $(0.024)$ & $(0.022)$ & $(0.020)$ & $(0.041)$ & $(0.035)$ & $(0.066)$ & $(0.037)$ & $(0.223)$ & $(0.022)$ \\
\hline $\begin{array}{l}\text { Time fixed } \\
\text { effect }\end{array}$ & Yes & Yes & Yes & Yes & Yes & Yes & Yes & Yes & Yes & Yes & Yes \\
\hline R-squared & 0.211 & 0.191 & 0.256 & 0.259 & 0.194 & 0.206 & 0.219 & 0.182 & 0.177 & 0.195 & 0.244 \\
\hline Observations & 3,302 & 413 & 1,364 & 2,744 & 3,770 & 681 & 1,002 & 315 & 552 & 306 & 2,117 \\
\hline
\end{tabular}

This table has the main regression results for each industry. The results are for 11 industries which are noted in row 1 . Clustered standard errors at the firm level are in parentheses, and ${ }^{* * * *} \mathrm{p}<0.01$, *** $\mathrm{p}<0.05,{ }^{*} \mathrm{p}<0.1$. 
The new pandemic requires the development of new drugs and treatment methods, so the impact of the pandemic in the medical and health industry are extremely significant. Moreover, the pandemic has also influenced people's lifestyles. Thus, the supply and demand of related products and the production and consumption structures have also changed accordingly. Furthermore, the government increased credit support for the manufacturing industry, which has a significant impact on the R\&D investment for raw materials and consumer goods. Therefore, the positive impacts of the pandemic on the innovation ability in these industries are more significant than that in other industries.

\section{Conclusion}

Using a fixed effect model, this study examines the impact of COVID-19 on enterprises' innovation ability. We use a panel dataset consisting of 3,001 Chinese A-share listed firms from the first quarter of 2019 to the second quarter of 2020. We also classify the enterprises according to their market values and industries to conduct subsample tests. The results show that the outbreak of coronavirus disease has significantly increased the R\&D investment of companies in China, both large-scale and small-scale. Moreover, the impact of COVID-19 is different for different industries.

Submitted: October 30, 2020 AEDT, Accepted: November 20, 2020 AEDT 


\section{REFERENCES}

Harrison, J. S., \& Freeman, R. E. (1999). Stakeholders, social responsibility, and performance: Empirical evidence and theoretical perspectives. Academy of Management Journal, 42(5), 479-485. https://doi.org/ $\underline{10.5465 / 256971}$

Iyke, B. N. (2020). Economic Policy Uncertainty in Times of COVID-19 Pandemic. Asian Economics Letters, 1(2). https://doi.org/10.46557/001c.17665

Jia, G. Q. (2020). Effect of Financial Development on the Real Economy --From the View of Aggregate Financing to the Real Economy. Journal of Industrial Technological Economics, 39(01), 77-86.

Keogh-Brown, M. R., \& Smith, R. D. (2008). The economic impact of SARS: How does the reality match the predictions? Health Policy, 88(1), 110-120. https://doi.org/10.1016/i.healthpol.2008.03.003
Lee, S. M., \& Trimi, S. (2020). Convergence innovation in the digital age and in the COVID-19 pandemic crisis. Journal of Business Research, 123, 14-22. https://doi.org/10.1016/j.jbusres.2020.09.041

Wen, H., Zhong, Q., \& Guo, Q. (2020). Does Bank Lending Intervention Hamper Firm Innovation? Evidence from the Chinese-style Capacity-Reduction Initiative. Asian Economics Letters.

Xiao, D. Y. (2013). Research on the Difference of $P$ / $E$ ratio of Listed Companies Based on Size

Classification. Shanghai Academy of Social Sciences.

Zhang, Y. Q., Zhang, W., \& Yao, L. P. (2019). Research on the Mechanism of Environmental Governance on Technological Innovation of Enterprises. CoOperative Economy \& Science, 7, 54-57.

Zhao, S., Li, G. H., \& Wang, Y. (2020). Supply Network Location, Absorptive Capacity and Firm Innovation Performance (pp. 1-12). Soft Science. 